\title{
Practise \& Belief of Santhara: Right to Die
}

\author{
Niharika Choudhary * and Divyansh Singh ${ }^{\dagger}$
}

\section{Abstract}

The article seeks to assert that the ritual of Santhara practiced by the followers of Jainism is not a suicide and discerns from the view of the Rajasthan High Court. The authors have used various sources on Santhara for research work and have analysed various case laws on right to die with dignity. At the outset, the article discusses the eminence of Santhara in Jainism. Further, it discusses the foundation of the 'essential practice' doctrine through various landmark judgements. The Rajasthan High Court has erred in holding that Santhara is not an essential practice in Jainism, when the same has been proved by Jain ascetics and religious denominations. The High Court ruling also contravenes the Supreme Court judgment, which holds that the right to life includes the right to a dignified life up to the point of death and would also encompass a dignified procedure for death. The article attributes the raison-d'être of the court, to the western perspective, overlooking the religious diversity of the Indian subcontinent and the various practices associated with different religions. Lastly, the article concludes that the Supreme Court needs

* Third Year, BBA LLB, National Law University, Jodhpur, India; niharikac1120@gmail.com

† Third Year, BSc LLB, National Law University, Jodhpur, India; divyansh402@gmail.com 
to lay emphasis on the difference between essentially religious and secular practices and re-affirm the right of religious freedom.

Keywords: Essential Practice, Religion, Right to Die, Santhara, Suicide.

\section{Introduction}

"Death is our friend, the truest of friends. He delivers us from agony. I do not want to die of a creeping paralysis of my faculties- a defecated man"

-Mahatma Gandhi

The Indian subcontinent is the birthplace of three great religions, namely Hinduism, Buddhism and Jainism, which is one of the oldest religions of the country. It is a pre-historic religion, dating back to $3000 \mathrm{BC}$, before the development of Indo-Aryan culture. Though there are many similarities that exist in the South Asian religions, certain parts of the belief systems are unique to each religion. According to Jain philosophy, the universe is composed of six substances which are indestructible. Two out of these six forms are the most important: Jiva (soul) and Ajiva (matter). The soul (Jiva) is either bonded or is liberated. It is a system of philosophy in which right conduct is a vital condition for spirituality as liberation can only be achieved by right conduct. Focus is on equanimity of thought and conduct. Fasting, meditation and other austerities are a part of the Jaina way of life. Penance occupies a unique place in Jainism. Perhaps, in the world religions, none parallels Jaina religion in the practice of penance, whose purpose is spiritual purification. ${ }^{1}$ The supreme object of ethical code of Jainism is to show the way for liberation of the soul from the bondage of Karma by cultivating the three jewels (ratna-traya), namely Right faith, Right knowledge and Right conduct, which constitute the path to

${ }^{1}$ Kokila H. Shah, The Jain Concept Of Sallekhana: A Loss or a Gain?, NATIONAL SEMINAR ON BIO ETHICS (2007), available at http://www.vpmthane.org/Publications (sample)/Bio-Ethics/Kokila\% 20H.\%20Shah\%201.pdf (last visited Dec. 27, 2015). 
it.2The highest importance in Jainism is attached to passionlessness. It teaches not only the art of a beautiful living but also the art of dying a dignified death. In Jainism, Sallekhana popularly known as 'Santhara' is a kind of ritual suicide undertaken as part of the process of reverence for all life and has traditionally been seen as a spiritual zenith for all Jain monks. The word sallekhana is actually 'sat+lekhana' meaning making his death an immortal act by firmly fixing his entire focus on his soul at the time of departure. Santhara is a posture adopted by a practitioner of Sallekhana. According to Jainism, all lives are sacred, based on which an ideal, of the refusal to do anything which would harm life at all. This embodies undertaking extreme steps such as the refusal of food and water to avoid killing anything, even microbes. Santhara is a slow method, whereby an individual slowly decreases his/her intake of food and liquids, ultimately leading to death. It is undertaken as a form of sacred vow. These vows were singularly named as 'Sallekhana' in the rock inscriptions at Sravana Belagola, a city located near Channarayapatna of Hassan district in Indian state of Karnataka, where the work called Retna Karvadaka gives the directions translated as follows:

When overtaken by portentous calamity, by famine, by old age or by disease for which there is no cure, to obtain liberation from the body for the sake of merit that Aryas call Sallekhana. He who is perfect in knowledge possess the fruit of all penance, which is the source of power; therefore should one seek for death by the performance of some meritorious vow, so far as his means will permit...... ${ }^{3}$

With the meditation of the five salutation mantras (pancanamaskaramantra), he should avoid the five transgressions: (1) a feeling that it would have been better if death would come a little later; (2) wishing for a speedy death; (3) entertaining fear as to how he would bear the pangs of death; (4) remembering friends and relatives at the time of death; (5) wishing for a particular kind of

2 T.K. TUKOL, SALLEKHANAISNOT SUICIDE 4 (L.D. Institute of Indology, 1976).

3 Lewis Rice, Jain Inscriptions at Sravana Beloga, THE INDIAN ANTIQUARY: A JOURNAL OF ORIENTAL RESEARCH 323-324 (1874). 
fruit as a result of penance. ${ }^{4}$ The basic concept underlying the vow is that, man who is the master of his own destiny should face death in such a way so as to prevent the influx of new Karmas, even at the last moment of his life and at the same time liberate the soul from the bondage of Karmas that may be clinging to it then. ${ }^{5}$

Today there are more than 4 million Jains in India. By an estimate, 300 Jains die every year across India due to such fasts and their deaths are usually celebrated publicly in the community. When a Jain feels that he has entered the final stage of life, with no more ventures in life to undertake, he may seek the permission of his guru, family, relatives and friends to take up the sacred vow of Santhara. Once approved, the Jain is permitted to gradually give up food and liquids. During this time, he must be ready to give up all worldly attachments and make peace with death.

However, recently this practice has been brought under the scrutiny by the Rajasthan High Court that termed it to be a criminal offence and equated it with suicide. The judgment delivered by the Rajasthan High Court in Nikhil Soni v. Union of India ${ }^{6}$ held that Santhara/Sallekhana were not an 'essential religious practice' of Jainism and there was no mention of such practice in Jain scriptures or religious texts. They rejected the claim that such a practice was to be protected under Article 25, 26 or 29 of the Constitution of India. The Rajasthan High Court appears to have erred in determining that Santhara is not an essential practice in Jainism. This article would first discuss as to what is meant by the term 'essential religious practice' and how it has evolved over time and the authority of the judges to determine a particular activity of a religion as essential or not.

\section{Defining the Essential Religious Practice Doctrine}

The first traces of the 'essential practices' doctrine dates back to the times when the makers of the Constitution were undergoing assembly debates while drafting the Constitution of India. It was

4 TUKOL, supra note 2 at 10.

5 TUKOL, supra note 2 at 7.

${ }^{6}$ Nikhil Soni v. Union of India \& Ors WRW 247/2015. 
Dr. B.R. Ambedkar, who mentioned this phrase in the Constituent Assembly Debates stating that:

The religious conceptions in this country are so vast that they cover every aspect of life, from birth to death. There is nothing which is not religion and if personal law is to be saved, I am sure about it that in social matters we will come to a standstill. I do not think it is possible to accept a position of that sort. There is nothing extraordinary in saying that we ought to strive hereafter to limit the definition of religion in such a manner that we shall not extend beyond beliefs and such rituals as may be connected with ceremonials which are essentially religious. It is not necessary that the sort of laws, for instance, laws relating to tenancy or laws relating to succession should be governed by religion. ${ }^{7}$

He had anticipated the need to differentiate between 'religious activities' and 'secular activities' in light of India's deeply ingrained religious beliefs and therefore had attached the word 'essential' to only religious activities, thereby leaving only the secular activities under the scrutiny of the judiciary. He was of the opinion that secular activities undertaken behind the veil of religion shall hamper the progress of the society. It is for this sole reason that the starting lines of Article 25 and Article 26 of the Indian Constitution lay down the restrictions to which an individual's right to freely practice, profess and propagate and manage the affairs of his religion is subjected to. Although not inscribed in any of the articles, the word 'essential' plays an important role in drawing a line between what is religious and what is secular.

In the case of S.R. Bommai v. Union of India, ${ }^{8}$ Justice P. B. Sawant gave a very clear distinction between what was religious and secular. He stated that notwithstanding the attitude of the state towards any religion, religious sects or denominations, religion could not be mixed with any of the secular activities of the state. He

7 Constituent Assembly Debates, Volume VII, available athttp:// parliamentofindia.nic.in/1s/debates/vol7p18b.html.

8 S.R. Bommai, AIR 1994 SC 1918. 
further stated that an individual's freedom of religion only extended to his activities done in pursuit of his spiritual life which is distinct from secular life. The activities undertaken in pursuit of spiritual life shall come under the exclusive domain of the affairs of the state. The word 'essential' was used to draw the thin line between secular and religious. Indian Courts have time and again attempted to determine what practices and activities have been or are fundamental to a religion. Such endeavours by the courts took the form of a doctrine and thus the name 'essential practice doctrine'.

The 'essential religious practice doctrine' as prescribed by Dr. B.R. Ambedkar was first used by the Supreme Court in the Shirur Mutt ${ }^{9}$ case. A petition was filed by the mahant of the Shirur Mutt monastery challenging the Madras Hindu Religious and Charitable Endowments Act, 1951 contending violation of Article 26 of the Indian Constitution. The Supreme Court laid down the following guidelines:

(1) The doctrines of the religion itself shall be used to determine whether a practice constitutes an essential practice in that religion or not.

(2) Complete autonomy shall be granted to a religious denomination or organisation in determining as to what rites and ceremonies are essential to their religion. Further, no interference shall be allowed by any outside authority to decide on such matters.

(3) The state shall have a right to regulate religious practices when such practices are in contradiction to "public order, health and morality" or are economic, commercial or political in nature.

Thus, the Supreme Court's interpretation of the doctrine is in line with what was propounded by Ambedkar. The judgment is significant because it clearly states that the authority of determination of an essential practice in a religion vests in the religious denominations and organisations. This led to the official

9 Commissioner, Hindu Religious Endowments, Madras v. Sri Lakshmindra Thirttha Swamiar of Shri Shirur Mutt, AIR 1954 SC 282. 
inception of the 'essential practices doctrine' in the jurisprudence of religion in India. Subsequently, matters under this doctrine were given protection under Article 25 and Article 26 of the Indian Constitution which provide protection to acts done in pursuance of religion, rituals and ceremonies observed.

The Supreme Court adjudicated upon the constitutionality of Bombay Trusts Act, 1950 which was alleged to have violated an individual's fundamental right under Article 25 and Article 26 of the Constitution of India in the case of Ratilal Panachand v. The State of Bombay and Ors. 10 Justice Mukherjea reiterated the principle as was laid down in the Shirur Mutt11 case. It was held that the religious acts and practices done in pursuit of religious beliefs were as much a component of religion as were faith and belief in the particular religious philosophy or doctrines. It was also stated that no outside authority had the right to declare any practice of religion as essential or non-essential. Further, no unconditional right was vested with any of the authorities of the state to discard, restrict or limit any religious practice, that they consider beneath the pretence of administering a verity estate.

Further, while comparing the Indian Constitution with the American and the Australian Constitutions, Justice Mukherjea stated that the Indian Constitution was an improvement over these constitutional texts, as Article 25 and Article 26 clearly states as to what can be regarded as religion. There were no limitations on the right to freedom of religion in the constitutional texts of United States of America and Australia. The limitations relating to public health, morality and social protection were laid down by the Australian and American courts through judicial pronouncements. The beauty of Indian Constitution lies in the fact that the constitution makers embodied these very restrictions in the constitution itself under Article 25 and Article 26, which have evolved through judicial pronouncements in other nations.

These two judgments played an essential role in defining a relationship between the state and organised religion. Sufficient amount of free play was given to religious denomination in

10 RatilalPanachand, AIR 1954 SC 388.

11 Shirur Mutt,AIR 1954 SC 282. 
regulating the matters of their religion. The approach of the Supreme Court in these two judgments was to use the 'essential practices doctrine' as a means to determine whether a particular practice was religious or secular, rather than determining whether the practice was essential to a religion.

However, the doctrine with its original meaning could not last long. In the early 1960's, judicial interpretation began to circumscribe the scope of religion, and judges took into their hands, the task of determining those crucial questions that were quite internal to a religion, there by attempting to define the nature of religion itself. The seeds of such shift in the interpretation of the 'essential practices doctrine' were sown in the case of Shri Venkatrama Devaru v. State of Mysore. ${ }^{12}$ The case dealt with the applicability of the Madras Temple Entry Authorisation Act , 1947 and the right of Harijans to enter the Sri Venkatrama Temple which was founded by the Gowda Saraswath Brahmins, who restricted the entry of Harijans into the temple. The Court, deciding the matter, went on to refer religious scriptures and case laws in order to examine the practice of restricting Harijans from entering the temples. It was held in this case that on certain special occasions and ceremonies, the temple authorities had the right to exclude certain persons.

The ruling in this case only partially applied the doctrine of essential practices. The Court accepted that religion encompassed rituals and practices but failed to appreciate the autonomy of a religious denomination or organisation to decide which ceremonies were essential. The Court's approach of referring to scriptures and validating the restriction upon Harijans was not only contradictory to the essential practices doctrine but was also not in consonance with the objective of the state to eliminate caste based discrimination.

It would not be wrong to mention that the original definition of the essential practices doctrine could not survive over a decade. The next case in line which gave a new direction to the doctrine was The Durgah Committee, Ajmer v. Syed Hussain Ali and Or. ${ }^{13}$ In this case,

12 Shri Venkatrama Devaru, AIR 1958 SC 255.

13 The Durgah Committee, Ajmer, AIR 1961 SC 1402. 
The Durgah Khawaja Sahet Act, 1955 was constitutionally challenged by the Khadims of shrine in Ajmer contending that the alleged Act abridged their right to manage the properties of the Durgah and also to receive aids and offerings from the pilgrims. Justice Gajendragadkar, by associating a secular history to the shrine upheld the validity of the Act. A note of caution was also issued which emphasized the role of the courts in determining as to what constituted an essential and integral part of religion and also distinguishing for the first time between irrational belief and religious practices. Thus, now the court had started acting as a gatekeeper, keeping a check on what practices qualified as religion.

A comparison of the cases of Shirur Mutt ${ }^{14}$ and Ratilal15 shows that the word 'essential' was used to determine whether the practice was religious or secular. A paradigm shift in outlook was witnessed and the doctrine was now being used to determine the importance of a practice within a religion.

Judgments of relevance to this shifting interpretation are delivered by Justice Gajendragadkar, which enhanced the authority of court in rationalizing religion, are Sri Govindlalji v. State of Rajasthan ${ }^{16}$ and Yagnapurushdasji v. Muldas. ${ }^{17}$ The ruling in these cases stated that the question of determining a practice as religious or secular and further determining the importance of a practice in a religion will always have to be decided by the courts. Thus, these series of rulings, over the decade, established that the questions relating to religious practice would always be subject to interpretation.

However, these rulings were in contradiction to what was the original meaning of the 'essential practices doctrine' as envisaged by Dr. B.R. Ambedkar and as held in the Shirur Mutt' RatilalPanachand ${ }^{19}$ cases.

\footnotetext{
14 Shirur Mutt,AIR 1954 SC 282.

15 RatilalPanachand, AIR 1954 SC 388.

16 Sri Govindlalji, AIR 1963 SC 1638.

17 Yagnapurushdasji, AIR 1966 SC 1135.

18 Shirur Mutt,AIR 1954 SC 282.

${ }^{19}$ RatilalPanachand, AIR 1954 SC 388.
} 
We can see that the present form of 'essential practices' doctrine does not hold the original meaning that was intended by the Constitutional drafters. The court should only have the authority to ask whether a particular religious ritual or practice is "sincerely held" by the followers of the religion which can be ascertained by the conduct of the adherents and the regularity with which the practice has been followed over ages. The authority to question the substantive nature of the practice itself should not be vested with the courts.

\section{Santhara - Suicide or Dignity in Death}

The Rajasthan High Court in the judgment equated the practice of Santhara to an act of voluntary suicide. The arguments raised by the Jain practitioners that, Santhara is not a practice to achieve unnatural death, rather it is a practice associated with a person's ethical choice to live with dignity until death, were not considered by the court. The reasoning provided by the Court was superficial and substantial justifications for its stance were not provided. The basic problem that lies, is in the application of a law inspired by the west which governs eastern religious notions and practices. The Indian Penal Code, 1860 which criminalises voluntary death was drafted by Lord Macaulay. The concept of suicide associated with religion is a repugnant one for the mainstream Anglo-Saxon West, whose Judeo-Christian beliefs would denounce such an act as antithetical to the moral and ethical principles espoused by Christianity. ${ }^{20}$ Lord Macaulay, an orthodox Christian drafted the code with a western outlook overlooking the varied religious diversity of the Indian subcontinent and the various practices associated with different religions. The eclectic religious texts born out of the Indian subcontinent have extensively deliberated on death from multiple viewpoints, and voluntary death in certain circumstances has been respected and exemplified through various religious heads, including Mahavira. A man has a moral right to

\footnotetext{
20 Shekhar Hattangadi,Santhara in the eyes of the Law, available at http:/ / www.thehindu.com/opinion/op-ed/Santhara-in-the-eyes-of-thelaw/article 7541803.ece.(last visited Dec., 2015).
} 
terminate his life as a part of religious freedom guaranteed under the Constitution of India. ${ }^{21}$

A better understanding of the Jaina concept of Santhara would reveal that it is not a form of suicide, rather, a means for self realisation. It is meant to free oneself from the bonds of the body, which are no longer useful. ${ }^{22}$ Santhara is neither the destruction of life out of passions; nor is it motivated by desires which characterize suicide. ${ }^{23}$ According to Jain philosophy, an impure death by suicide involves increase in passions; a pure death, as in Sallekhana, does not. In Jainism, passions are seen as a direct cause of the influx of Karma impurities to the soul and thus, they result in rebirth at a lower level, while a passionless state of mind leads to both the cessation of the accumulation of Karma and the destruction of existing karma that is already attached to one's soul. ${ }^{24}$

Santhara is a multivalent term which cannot be reduced to the dreariness of suicide as closure or termination. Santhara performed correctly, is a ritual of non-violence. ${ }^{25}$ Except for physical death, there is nothing similar between suicide and Santhara. A person usually commits suicide or attempts to do so when he is going through certain conflicts in his mind, some feeling of guilt, hopelessness and the inability to deal with a problem which can be of a very serious nature. Frustration, exhaustion in life, anxiety, depression, mental insanity or arousal of any passion through abetment may also be the reasons. On the other hand, no such factors motivate a person to adopt Santhara. There is no feeling of guilt, disgrace or disgust in oneself. It is the individual's free choice to face death in a bold and calm manner. Another essential

21 Kriti Sharma, Santhara: Jains' Right to Exit with Dignity, available at http://ohrh.law.ox.ac.uk/Santhara-jains-right-to-exit-with-dignity. (last visited Dec., 2015).

22 Shah, supra note 1.

${ }^{23} \mathrm{Id}$.

24 MARGARET PABST BATTIN, THE ETHICS OF SUICIDE: HISTORICAL SOURCES 47 (U.S.A: Oxford University Press, 2015).

25 Shiv Visvanathan, A Reductive Reading of Santhara, THEHINDU, available at http:/ / www.thehindu.com/opinion/lead/a-reductive-reading-ofSanthara/article7572187.ece. (last visited Dec., 2015). 
difference between the two acts is that certain means might be employed by a person committing suicide, that is, use of weapons to kill oneself, however no means are employed to bring about death in the practice of Santhara. In Jaina texts and scriptures, people who commit suicide are defined as "those who use weapons, throw themselves into the fire and water and are liable to be caught in the wheel of Samsara" ${ }^{26}$ Fasting unto death, if based on force, is against the spirit of non-violence the basic tenet of Jainism. Jaina religion forbids all kinds of purposeless violence. Consequently, except fasting unto death, all other methods of voluntary chosen death are forbidden in Jainism. ${ }^{27}$ Further, unlike suicide there is nothing done in secrecy by a person taking the vow of Santhara. It is not a speedy procedure either. There are various pre-conditions that need to be fulfilled: the family members are consulted, permission is sought from the spiritual guru, and all the family members and relatives are informed about the vow of Santhara. It is a high spiritual achievement which is celebrated and no condolences are held for the departed soul. Therefore, it cannot be declared as an act of suicide in any manner.

Further, the Rajasthan High court incorrectly referred to the case of Smt. Gian Kaur v. State of Punjab ${ }^{28}$ and held that right to life does not include the right to die. It simply stated that Santhara was an act of suicide and there was no dignity in such an act. No proper examination was done as to whether Santhara actually fits into or equates to suicide in any manner. The Gian Kaur ${ }^{29}$ case clearly stated that the right to life includes the right to live with human dignity. Such a right would exist up to the end of a natural life. Further, this also includes the right to a dignified life to the point of death and would also encompass a dignified procedure of death. It was clearly explained by the Supreme Court that a right to life may also include the right of a dying man to die with dignity when his life is ebbing out.

${ }^{26}$ Gian Kaur v. State of Punjab, AIR 1996 SC 946.

27 Shah, supra note 1.

28 Smt. Gian Kaur, AIR 1996 SC 946.

${ }^{29} \mathrm{Id}$. 
The Rajasthan High Court Judgment in Nikhil Soni v. Union of India ${ }^{30}$, wherein it decided there was no dignity in Santhara and it was a way of ending one's life unnaturally, is likely to have sweeping consequences, not only amongst the Jain community in Rajasthan but conjointly across the country. Unfortunately, it conflates many essential issues of constitutional law, and reflects the confusion over the basic guarantee of religious freedom in our constitutional jurisprudence. The Court not only denies the community constitutional protection, but additionally takes upon itself the task of re-characterising the religion in an exceedingly progressive light, and in a sense, produces new social facts through its holdings.

\section{Conclusion}

The centuries-old ritual of Santhara has been under scrutiny since 2006, when the case of 93-year-old Keila Devi Hirawat from Jaipur invited international debate on whether there was any place for such a ritual within modern times. Today, Santhara stands as a classic example of the challenge that every faith-based society faces due to pressures placed upon them to follow modern and secular norms. On one hand, there is a challenge to balance individual freedom and personal liberty as a minority community's spiritual rights, and on the other, the necessity for state intervention in matters of faith. Santhara is a spiritual practice of meeting the challenge of death and can by no reasonable construction be equated to suicide. As held by the Apex Court, a person's right to live with dignity also includes the right of a dying man to die with dignity. This practice forms an essential religious practice in Jainism as proved by Jain ascetics and religious denominations by appreciating the continuance of such practice since the very inception of the religion. The Nikhil Soni judgment not only affects a spiritual group's freedoms bonded within the Constitution, but also conjointly features continuing dialogue on the right to die with dignity. While the Supreme Court is yet to conclusively determine the matter, it is imperative that the court adopts a cautious

${ }^{30}$ Nikhil Soni v. Union of India\& Ors., WRW 274/2015. 
approach in its choice and understanding of precedents, as the same are likely to be misconstrued.

The Supreme Court should not only declare the practice as 'essentially religious' and provide protection to the same under the Constitution but should also reconsider its present view on the 'essential practices doctrine'. It needs to revert to the original definition of the 'essential practices doctrine' as was envisaged by Dr. B.R. Ambedkar in the Constituent Assembly Debates. The emphasis should be laid to differentiate between an essentially religious and a secular practice. The court's authority should not extend to taking the job of religious heads and determining as to what constitutes an essential practice within a religion. Such assumption of power by the Courts has already caused the weakening of the fundamentally inscribed religious freedom in India. Further, continuance of the doctrine with its present interpretation is definitely bound to have negative ramifications. Religion should be accepted as is being represented by its practitioners. What the judiciary needs to consider while bringing down any religious practice is whether such practice is hampering societal modifications, is causing any societal inequality or is violating any individual's rights. 